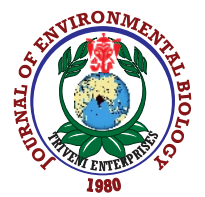

\title{
Evaluation of Enterococcus hirae LAB3 as potential probiont against Vibrio harveyi in Artemia nauplii and Asian seabass larvae (Lates calcarifer) cultures
}

\author{
F. Masduki ${ }^{1,2}$, T. Zakaria', C.C. Min ${ }^{1,2}$ and M. Karim ${ }^{1,3 *}$ \\ ${ }^{1}$ Department of Aquaculture, Faculty of Agriculture, Universiti Putra Malaysia, Serdang, 43400, Malaysia \\ ${ }^{2}$ Laboratory of Marine Biotechnology, Institute of Bioscience, Universiti Putra Malaysia, 43400, Serdang, Malaysia \\ ${ }^{3}$ Laboratory of Sustainable Aquaculture, International Institute of Aquaculture and Aquatic Sciences (UPM), Port Dickson, 70150, Malaysia \\ *Corresponding Author Email : murnimarlina@upm.edu.my
}

Paper received: 18.09 .2019

Revised received: 10.11 .2019

Accepted: 14.08 .2020

\section{Abstract}

Aim: To evaluate the ability of Enterococcus hirae strain LAB3 to inhibit the growth of $V$. harveyi in in-vitro co-culture assay and confer protection towards Artemia nauplii and seabass larvae against $V$. harveyi in in-vivo assay.

Methodology: Enterococcus hirae was co-cultured with V. harveyi for $96 \mathrm{hrs}$ and the samples were taken every $6 \mathrm{hr}$ interval to determine the growth of the pathogen in in-vitro assay. In the in-vivo assay, E. hirae at different concentrations were introduced to the Artemia nauplii and seabass larvae cultures. After 24 -hr incubation period, V. harveyi at concentration $10^{6} \mathrm{CFU} \mathrm{ml^{-1 }}$ were added into the respective experimental tanks. Mortality was observed and recorded daily, until $50 \%$ mortality was observed in negative control group which challenged with $V$. harveyionly.

Results: $E$. hirae was able to reduce the numbers of $V$. harveyi after $12 \mathrm{hr}$ of co-culture incubation. In addition, E. hirae was administered into the Artemia nauplii and conferred protection against $V$. harveyi with the best survival rate at concentration of $10^{6}$ CFUmL $^{-1}(70 \pm 3.1 \%)$. The untreated group seabass larvae challenged with $V$. harveyi presented low survival of $(16.7 \pm 3.3 \%)$, while fish treated with probiotic $E$. hirae at $10^{6} \mathrm{CFUm}^{-1}$ showed significantly increased survival rates $(68.3 \pm 0.9 \%)$ after challenged. The survival of healthy unchallenged fish treated with probiotic was not significantly different with the control group. The pathogen loaded also reduced in groups treated with $E$. hirae respectively.

Interpretation: $E$. hirae strain $\mathrm{LAB} 3$, a potential probiont was able to reduce the number of Vibrios and conferred protection to Artemia and seabass larvae.

Key words: Artemia nauplii, Enterococcus hirae, Probiotic, Seabass larvae, V. harveyi

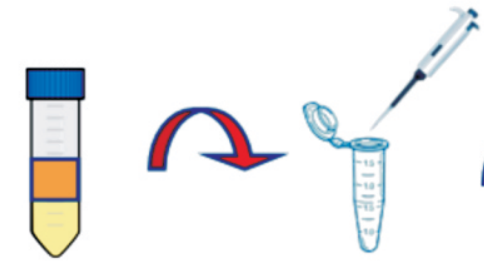

Samples were

Enterococcus hirae was co cultured with Vibrio harveyi for 96 hours

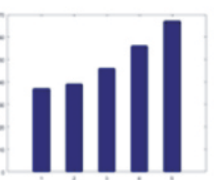

Survival and mortality was observed and recorded daily and experiment ended when $50 \%$ mortality occurred in the negative control group taken every $6 \mathrm{hr}$
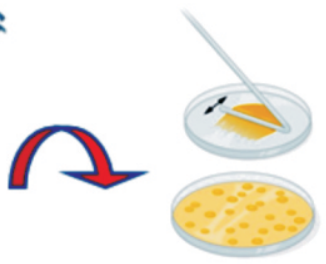

Plate count was done to observe any Vibrios reduction
After a 24-hr incubation period, V. harveyi at concentration $10^{6} \mathrm{CFU} \mathrm{ml^{-1 }}$ were added into the respective experimental tanks.
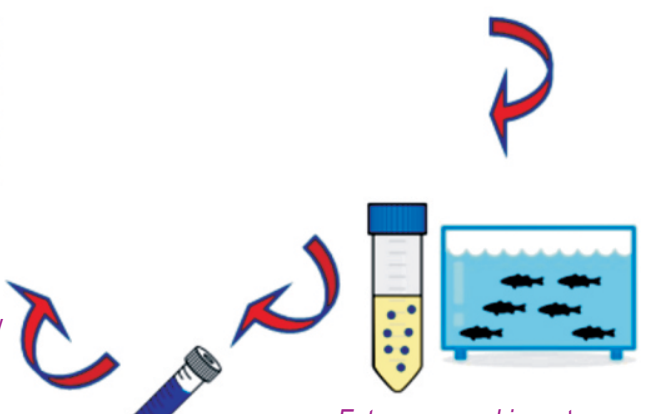

Enterococcus hirae at different concentrations were introduced to the Artemia nauplii and seabass larvae cultures

How to cite : Masduki, F., T. Zakaria, C.C. Min and M. Karim: Evaluation of Enterococcus hirae LAB3 as potential probiont against Vibrio harveyi in Artemia nauplii and Asian seabass larvae (Lates calcarifer) cultures. J. Environ. Biol., 41, 1153-1159 (2020). 


\section{Introduction}

Intensification of fish farming industry has increased the incidence of diseases that has become major constraint to the system resulting in economic loss (Stentiford et al., 2012; Joffre et al., 2018). In euryhaline fish farming, the potential pathogenic bacteria belongs to Vibrio spp. Vibrios belong to Harveyi clade and are considered as important pathogens for a large number of marine animals in the aquaculture industry (Vanmaele et al., 2015). Vibrio harveyi express the virulence factor known as gene product enabling them to infect and damage the host (Defoirdt et al., 2014). Meanwhile, In Malaysia, outbreak of vibriosis reported in year 2008 in open cage in Sabah mainly caused by $V$. harveyi infection among the fish stocked lead to huge loses (Ransangan et al., 2012). In addition, V. harveyi is known as pathogenic organism associated with luminous vibriosis that causes mortality in penaeid shrimp farm (Wang et al., 2015) and is highly infectious at early stages of fish (Nandi and Ray, 2017). Application of antimicrobials as well as chemicals have been well documented to portray beneficial effects to infected animals. However, it might be hazardous to the environment due to microbial resistance developed by pathogens (Romero et al., 2012). Hence, holistic approaches that include pathogen, host, and environment can be more effective for long term usage (Defoirdt et al., 2011). It refers to the strategies directed toward pathogenic bacteria without using antibiotics as a preventive method. For past few years, using probiotics have been the most promising preventive method in controlling pathogens in fish culture (KesarcodiWatson et al., 2008). Generally, probiotics known as beneficial microorganisms work as a live microbial feed supplement when administered in appropriate amount are beneficial to the host (Fuller, 1989; FAO, 2001; Lara Flores and Aguirre-Guzman, 2009). The diversity of probiotics in the host gut is correlated with their habitats and closely interacts with these microbes. For instance, probiotics of Bacillus, Lactobacillus and Enterococcus have the potential to influence the immune system of the host (Sayes et al., 2018). However, administration of probiotic in live fish feed such as Artemia was reported to be an interesting but rarely studied. Due to the fact that live feed plays an important role in dietary systems, especially at larval stages of fish and shellfish (Haq et al., 2011). Various live feed have been used commercially in aquaculture. Artemia is widely used in marine finfish and crustacean hatcheries due to high nutrient content and is used as vector for probiotic as an excellent preliminary model organism (Soltanian et al., 2007). Enterococcus hirae strain LAB3 isolated from the intestine of seabass and have been undergoing several in-vitro assay to assess their potential as probiotics. In a study, LAB3 showed positive characteristics of probiotic as it was able to grow at $\mathrm{pH} 2$ to $\mathrm{pH} 10$ within $3 \mathrm{hr}$ incubation period as well was as able to secrete some extracellular enzymes and produce biofilm up to $30 \mathrm{hr}$ incubation period. Exhibit resistance to low $\mathrm{pH}$ is a crucial key to be appointed as probiotic (Noriega et al., 2004; Fathiah Masduki, 2018). Moreover, probiotics that secrete and synthesize different extracellular enzymes are able to improve feed utilization for better growth rate (Balzacar et al., 2006). Invitro evaluation prior to in-vivo testing is a good indicator for probiotic effectiveness in controlling disease in host (Balzacar et al., 2006; Aly et al., 2008). Thus, present study aimed to evaluate the protective effect of potential probiotic $E$. hirae strain LAB3 towards Artemia nauplii and Asian seabass larvae after challenged with $V$. harveyi.

\section{Materials and Methods}

Bacterial strains and culture condition: E. hirae strain $L A B 3$ (Accession number: MK757970) isolated previously from the intestine of healthy Asian seabass was used in this study. Meanwhile, V. harveyi was isolated from diseased Asian seabass. Probiont was grown in Man Rogosa and Sharp (MRS, Himedia, India) broth supplemented with $1.5 \% \mathrm{NaCl}$ while pathogen was cultured in Trypticase Soy Broth (TSB, Difco, USA) supplemented with $1.5 \% \mathrm{NaCl}$ at $30^{\circ} \mathrm{C}$ for $24 \mathrm{hr}$.

Growth inhibition in co-culture assay: Candidate probiotic strain was tested for antagonistic effect against Vibrio harveyi using broth co-culture assays. In this assay, the initial density of $V$. harveyi was calculated to be approximately $10^{5} \mathrm{CFUml}^{-1}$, while

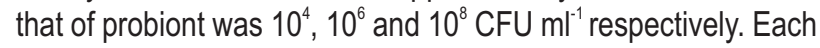
pathogen and probiotic inoculum were co-cultured in $10 \mathrm{ml} \mathrm{TSB}$ supplemented with $1.5 \% \mathrm{NaCl}$ and incubated at $30{ }^{\circ} \mathrm{C}$, respectively. Sample was taken at 0,6,12, 24, 48 and $96 \mathrm{hr}$ of incubation. A $100 \mu$ l of culture from each inoculum was plated on Thiosulfate Citrate Bile Salt Sucrose (TCBS, Difco, USA) agar in order to quantify the number of cells. All plates were incubated overnight at $30^{\circ} \mathrm{C}$. The number of colonies for each inoculum was recorded as CFU $\mathrm{ml}^{-1}$ and counted by the formula:

CFU $\mathrm{ml}^{-1}=($ No. of colonies $\mathrm{x}$ dilution factor) / Volume of culture plate $(\mathrm{ml})$

Challenge of Artemia nauplii enriched with probiotic against V. harveyi : Experiment was performed on Artemia salina cyst (Bio-Marine, USA). Artemia cyst were hatched for $24 \mathrm{hr}$, at 28-30 ${ }^{\circ} \mathrm{C}$ in $35 \mathrm{ppt}$ of filtered sterile seawater with continuous aeration and light intensity. After $24 \mathrm{hr}, 20$ nauplii were divided into sterile $50 \mathrm{ml}$ falcon tube filled with $30 \mathrm{ml}$ of filtered sterile seawater (Table 1). Artemia were first pre-incubated for $24 \mathrm{hr}$ with probiont in three different concentrations $\left(10^{4}, 10^{6}\right.$ and $\left.10^{8} \mathrm{CFU} \mathrm{m}^{-1}\right)$. After $24 \mathrm{hr}$ incubation, V. harveyi was introduced at $10^{5} \mathrm{CFU} \mathrm{m{ } ^ { - 1 }}$. All the tubes were kept on orbital shaker for continuous aeration purpose. Observation was made until $50 \%$ mortality occurred in the group that contained Artemia and pathogen only. Survival of Artemia was recorded and the data were analyzed.

Challenge of fish larvae enriched with probiotic against V. harveyi : Twenty three-day-old asian seabass larvae (approximately weighting $0.34 \mathrm{~g}, 2.5-2.9 \mathrm{~cm}$ long), was procured 
Table 1: Treatments in Artemia challenge assay

\begin{tabular}{|c|c|}
\hline Treatments & Descriptions \\
\hline $\mathrm{T} 1$ & Artemia only \\
\hline $\mathrm{T} 2$ & Enterococcus LAB3 $10^{4} \mathrm{CFUmL}^{-1}$ \\
\hline T3 & Enterococcus LAB3 $10^{6} \mathrm{CFUmL}^{-1}$ \\
\hline T4 & Enterococcus LAB3 $10^{8} \mathrm{CFUmL}^{-1}$ \\
\hline T5 & Vibrio harveyi $10^{5} \mathrm{CFUmL}^{-1}$ \\
\hline T6 & Enterococcus LAB3 $10^{4} \mathrm{CFUmL}^{-1}+$ Vibrio harveyi $10^{5} \mathrm{CFUmL}^{-1}$ \\
\hline $\mathrm{T7}$ & Enterococcus LAB3 $10^{6} \mathrm{CFUmL}^{-1}+$ Vibrio harveyi $10^{5} \mathrm{CFUmL}^{-1}$ \\
\hline T8 & Enterococcus LAB3 $10^{8} \mathrm{CFUmL}^{-1}+$ Vibrio harveyi $10^{5} \mathrm{CFUmL}^{-1}$ \\
\hline
\end{tabular}

Table 2: Treatments of seabass larvae challenge test

\begin{tabular}{|c|c|}
\hline Treatments & Descriptions \\
\hline T1 & Control \\
\hline T2 & Vibrio harveyi $10^{5} \mathrm{CFUmL}^{-1}$ \\
\hline T3 & Enterococcus hirae LAB3 $10^{4} \mathrm{CFUmL}^{-1}$ \\
\hline T4 & Enterococcus hirae LAB3 $10^{6} \mathrm{CFUmL}^{-1}$ \\
\hline T5 & Enterococcus hirae LAB3 $10^{8} \mathrm{CFUmL}^{-1}$ \\
\hline T6 & Enterococcus hirae LAB3 $10^{4}+$ Vibrio harveyi $10^{5} \mathrm{CFUmL}^{-1}$ \\
\hline $\mathrm{T} 7$ & Enterococcus hirae LAB3 $10^{6}+$ Vibrio harveyi $10^{5} \mathrm{CFUmL}^{-1}$ \\
\hline T8 & Enterococcus hirae LAB3 $10^{8}+$ Vibrio harveyi $10^{5} \mathrm{CFUmL}^{-1}$ \\
\hline
\end{tabular}

from by FRI Gelang Patah, Johor, Malaysia and acclimatized for 2 days prior to use. All experiments were conducted in triplicates with 15 larvae per experimental tank (Table 2). A negative control group consisted larvae that were neither treated with probiotics nor challenged with pathogens. The positive mortality control was the group that was challenged with pathogens but was not treated with probiont. E. hirae was introduced on the first day using immersion method into the culture water at $10^{4}$ and $10^{6} \mathrm{CFU} \mathrm{ml}^{-1}$, respectively. After 24 -hrs, the larvae were challenged with $V$. harveyi at a concentration of $10^{5} \mathrm{CFU} \mathrm{ml}{ }^{-1}$. Observations were made until $50 \%$ mortality was observed in positive mortality control group. Survival and mortality were observed and recorded daily.

Reduction on pathogen loads: Once the experiment ended, the number of pathogen loads were determined in the host and culture water. As for Artemia, a sterile $100 \mu \mathrm{m}$ mesh was used. Host (Artemia and seabass larvae) were mashed and homogenized using sterilized stick for Artemia and also mortar and pestle for seabass larvae. Serial dilution was made up to $10^{8}$ to quantify the number of Vibrios. To determine the pathogen loads in host and culture water, $100 \mu$ l of each sample was plated on TCBS agar with triplicate each. The plates were incubated at $30{ }^{\circ} \mathrm{C}$ for $24 \mathrm{hr}$ and the number of colonies were calculated as CFU mll.

Statistical analyses : Statistical analysis was performed using one-way analysis of varience (ANOVA) followed by Tukey test in order to test for significant differences between the groups. Statistical significance was tested at probability level of 0.05 .

\section{Results and Discussion}

The antagonistic effects of potential probiotic strain was tested for the growth of $V$. harveyi in broth co-culture assays. The results demonstrated that $E$. hirae managed to reduce the growth of $V$. harveyi 12 to $48 \mathrm{hrs} .10^{4}$ and $10^{6} \mathrm{CFUm} \mathrm{I}^{-1}$ probiont inhibited the growth of $V$. harveyi significantly. Whereas in control groups, the growth of pathogens increased gradually with time until $48 \mathrm{hr}$ incubation. All the probionts treatment significantly decreased $(p<0.05)$ the number of pathogens.

In order to evaluate any possible protection offered to Artemia by the probionts, the nauplii were treated with probiont (Fig. 2). The results demonstrated that the survival rate of Artemia inoculated with $10^{6} \mathrm{CFU} \mathrm{m^{-1 }}$ probiont was higher $(70 \pm 3 \%)$ compared to Artemia treated with pathogen alone (13.3 $\pm 2 \%)$. Challenged groups of Artemia with $10^{4}$ and $10^{6} \mathrm{CFUml}^{-1}$ probiont showed increase in the survival rate $(50-70 \%)$ compared to Artemia treated with $V$. harveyionly.

Fig. 3 indicated that, larvae treated with $10^{6} \mathrm{CFUml}^{-1} \mathrm{E}$. hirae LAB3 (T3) showed the highest survival rate $(66.7 \%)$ with no significant difference $(p>0.05)$ with the control group $(70 \%)$. Larvae treated with $E$. hirae LAB3 at $10^{4} \mathrm{CFU} \mathrm{ml^{-1 }}$ and $10^{8} \mathrm{CFUml}^{-1}$ showed survival rate of $46.7 \%$ and $18.3 \%$ respectively, which significantly differed $(p<0.05)$ with the control group. Among the treatments, $10^{8} \mathrm{CFUml}^{-1}$ concentration was found harmful to the host. In the challenge assay (Fig. 3), survival rate of negative control group was $16.7 \%$. Meanwhile, survival of seabass larvae treated with probiont and challenged with $V$. harveyi was $36.7 \%$ in 


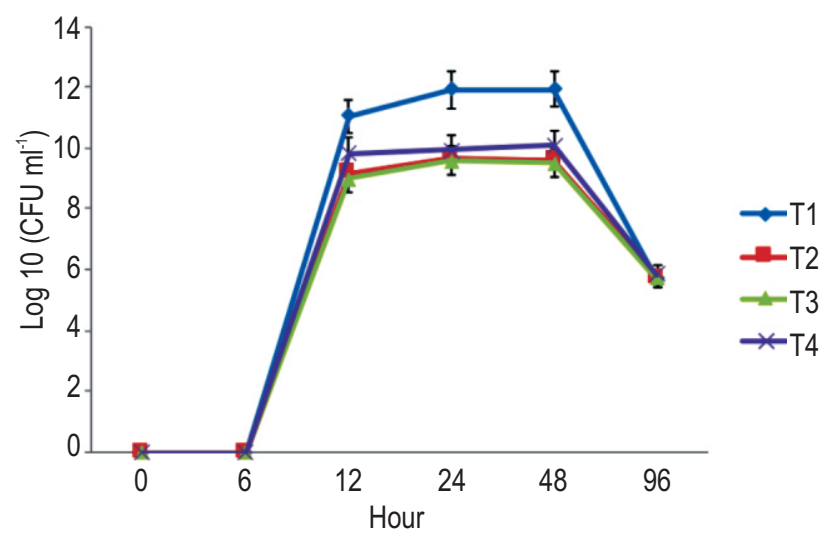

Fig. 1 : Growth pattern of Vibrio harveyi at $10^{5} \mathrm{CFUml}^{-1}$ incubated with different concentrations of Enterococcus hirae against time. T1 (Vibrio harveyi $10^{5} \mathrm{CFUml}^{-1}$ ), T2 (Vibrio harveyi $10^{5} \mathrm{CFUml}^{-1}+$ Enterococcus hirae $10^{4} \mathrm{CFUml}^{-1}$ ), T3 (Vibrio harveyi $10^{5} \mathrm{CFUml}^{-1}+$ Enterococcus hirae

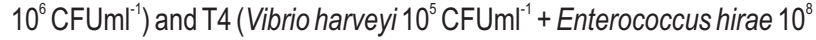
CFUmll $\left.{ }^{-1}\right)$. Different alphabet indicates significant differences among treatments $(p<0.05)$

group T6 $\left(10^{4} \mathrm{CFU} \mathrm{ml}{ }^{-1}\right)$ and $68.3 \%$ in $\left.\mathrm{T} 7\left(10^{6} \mathrm{CFU} \mathrm{ml}\right)^{-1}\right)$, respectively.

Enterococcus hirae LAB3 was able to reduce the pathogen load in both culture water and Artemia. The number of Vibrios in Artemia reduced significantly after treatment with the probionts as compared with the control group (T2). The highest reduction was observed at $10^{6} \mathrm{CFU} \mathrm{ml}^{-1}\left(5.82 \mathrm{CFU} \mathrm{ml}^{-1}\right)$. In culture water, group 77 treated with $10^{6} \mathrm{CFU} \mathrm{ml^{-1 }}$ E. hirae also showed the highest reduction $\left(1.69 \pm 0.86 \mathrm{CFU} \mathrm{ml}^{-1}\right)$ as compared with other treatments (Table 3 ).

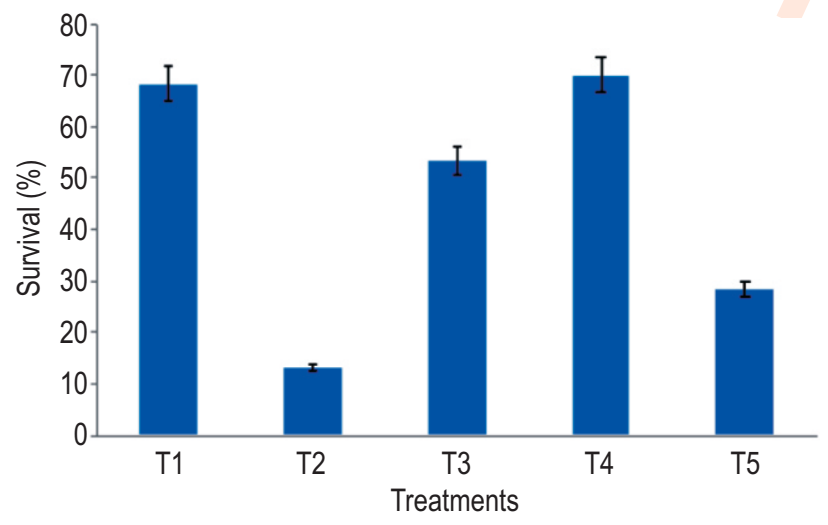

Fig. 2 : Survival of Artemia after pre-incubated with probiont Enterococcus hirae Error bars indicate standard error. Different alphabet indicates significant difference among treatments $(p<0.05)$. T1 (Control), T2 (Vibrio harveyi $10^{5} \mathrm{CFUml}^{-1}$ ), T3 (Enterococcus hirae LAB3 $10^{4}$ CFUml ${ }^{-1}+$ Vibrio harveyi $10^{5} \mathrm{CFUml}^{-1}$ ), T4 (Enterococcus hirae LAB3 $10^{6}$ CFUml ${ }^{-1}+$ Vibrio harveyi $10^{5} \mathrm{CFUml}^{-1}$ ), T5 (Enterococcus hirae LAB3 $10^{8}$ $\mathrm{CFUml}^{-1}+$ Vibrio harveyi $\left.10^{5} \mathrm{CFUml}^{-1}\right)$.
Similar results were obtained for seabass larvae where significant reduction of vibrios were observed in culture water as well as in larvae after treated with $E$. hirae at $10^{6} \mathrm{CFU} \mathrm{m} \mathrm{^{-1 }}$ compared to the untreated larvae (Table 4).

Overuse of antibiotics in treating fish infections in aquaculture has led to search a novel alternative method such as usage of probiotics (Gomez-Gil et al., 2002). Use of probiotics as growth promoter and immune modulator system in fish has been investigated (Mohapatra et al., 2012). In recent years, manipulation of bacterial load in the live feed may contribute as a valuable mechanism for increasing the larval growth and survival rates (Villamil et al., 2003). Since microbiological pollution in the environment due to the administration of probiotics in culture water, cooperation between live feed and probiotics can possibly became an alternative approach in aquaculture. Hence, the present study demonstrates that $E$. hirae LAB3 can serve as a probiont to inhibit the growth of $V$. harveyi in in-vitro co culture assay and confer protection to the Artemia and seabass larvae after challenged with $V$. harveyi in-vivo studies. Co-culture assay was done to demonstrate the growth pattern of $V$. harveyi after incubating with the probiont $E$. hirae along with inoculation period intervals. The results showed that, probiont $E$. hirae LAB3 managed to reduce the growth of $V$. harveyi from 24 to $96 \mathrm{hr}$ respectively. All the concentrations showed significant results compared to the control group. Probiont $E$. hirae was able to inhibit the growth of $V$. harveyi significantly within $48 \mathrm{hr}$ of incubation.

Probiotics can be delivered into cultured organism in two ways. It can be blended with feed and administrated orally or through proliferation in water medium and exclude pathogenic

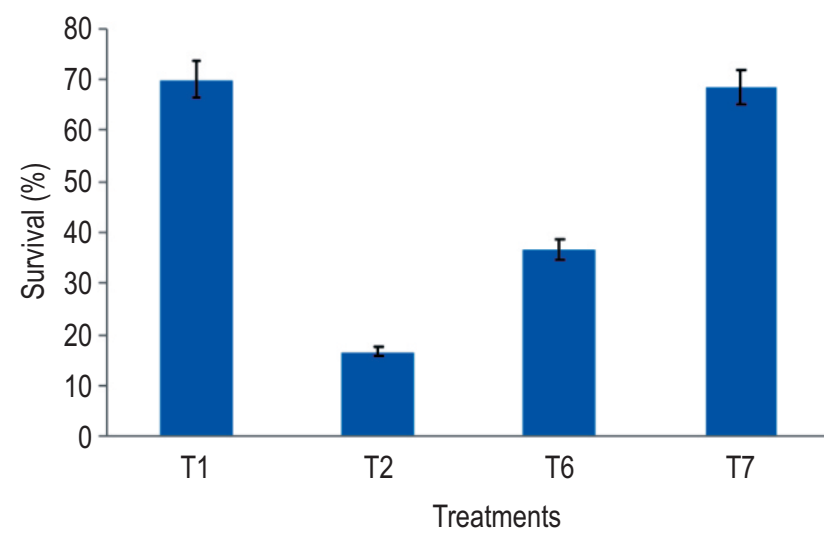

Fig. 3 : Survival of seabass larvae after pre-treated with probiont Enterococcus hirae LAB3 and challenged with Vibrio harveyi. Error bars indicate standard error. Different alphabet indicates significant differences among treatments $(p<0.05)$. T1 (Control), T2 (Vibrio harveyi $10^{6} \mathrm{CFUml}^{-1}$ ), T6 (Enterococcus hirae LAB3 $10^{4} \mathrm{CFUml}^{-1}+$ Vibrio harveyi $10^{6} \mathrm{CFUml}^{-1}$ ), T7 (Enterococcus hirae LAB3 $10^{6} \mathrm{CFUml}^{-1}+$ Vibrio harveyi $\left.10^{6} \mathrm{CFUml}^{-1}\right)$. 
Table 3 : Vibrios count in culture water and Artemia after pre-incubated at different concentrations of Enterococcus hirae LAB3 $\left(10^{4}, 10^{6}\right.$ and $\left.10^{8} \mathrm{CFUml} \mathrm{F}^{-1}\right)$ and challenged with $10^{5} \mathrm{CFUml}^{-1}$ of Vibrio harveyi. Different alphabet indicates significant differences among treatments $(p<0.05)$

\begin{tabular}{llll}
\hline Treatments & Descriptions & \multicolumn{2}{c}{${\text { Log } 10 \mathrm{CFUml}^{-1}}^{\text {Artemia }}$} \\
\cline { 3 - 4 } & & Culture water & $6.62 \pm 0.11^{\mathrm{b}}$ \\
\hline T2 & ${\text { Vibrio harveyi } 10^{5} \mathrm{CFUmL}^{-1}}_{\mathrm{T}}$ & $5.65 \pm 0.64^{\mathrm{a}}$ & $6.05 \pm 0.06^{\mathrm{a}}$ \\
T7 & Enterococcus hirae LAB3 $10^{4}+$ Vibrio harveyi $10^{5} \mathrm{CFUmL}^{-1}$ & $3.67 \pm 0.12^{\mathrm{b}}$ & $5.82 \pm 0.05^{\mathrm{a}}$ \\
T8 & Enterococcus hirae LAB3 $10^{6}+$ Vibrio harveyi $10^{5} \mathrm{CFUmL}^{-1}$ & $1.69 \pm 0.86^{\mathrm{c}}$ & $6.11 \pm 0.14^{\mathrm{a}}$ \\
\hline
\end{tabular}

Table 4 : Vibrios count in culture water and larvae after pre-incubated at different concentrations of Enterococcus hirae LAB3 $\left(10^{4}, 10^{6} \mathrm{CFUml}{ }^{-1}\right)$ and challenged with $10^{6} \mathrm{CFUml}^{-1}$ of Vibrio harveyi. Different alphabet indicates significant differences among treatments $(\mathrm{p}<0.05)$

\begin{tabular}{|c|c|c|c|}
\hline \multirow[t]{2}{*}{ Treatments } & \multirow[t]{2}{*}{ Descriptions } & \multicolumn{2}{|c|}{$\log _{10}$ CFUml $^{-1}$} \\
\hline & & Culture water & Larvae \\
\hline T2 & Vibrio harveyi $10^{5} \mathrm{CFUmL}^{-1}$ & $5.65 \pm 0.16^{\mathrm{a}}$ & $6.98 \pm 0.16^{a}$ \\
\hline T6 & Enterococcus hirae LAB3 $10^{4}+$ Vibrio harveyi $10^{5} \mathrm{CFUmL}^{-1}$ & $3.67 \pm 0.21^{b}$ & $5.80 \pm 0.21^{b}$ \\
\hline $\mathrm{T} 7$ & Enterococcus hirae LAB3 $10^{6}+$ Vibrio harveyi $10^{5} \mathrm{CFUmL}^{-1}$ & $1.69 \pm 0.16^{c}$ & $4.47 \pm 0.16^{c}$ \\
\hline
\end{tabular}

bacteria by consuming all available nutrients (Azrin et al., 2017). Artemia was used in preliminary in-vivo challenged test in this study. Additionally, Artemia is considered a perfect candidate for preliminary interaction study between host and microbes (Lamari et al., 2014). Despite being a model host for challenge assay, it is commonly used as a medium for introducing probiotics to the cultured species (Seenivasan et al., 2012). Macrobrachium rosenbergii postlarvae fed with Artemia fransiscana enriched with probiotic Enterococcus durans proves to have fewer pathogen load in their gut microflora compared to postlarvae fed with unenriched Artemia (Bhaheerathan et al., 2020)

The findings of this study demonstrate that incubation of probiont $E$. hirae showed the ability to increase the survival of Artemia challenging with $V$. harveyi. These findings also corroborates with the finding of Lamari et al. (2014) where Artemia treated with probiotic Lactobacillus casei showed higher survival and faster growth rate when challenged with $V$. alginolyticus. Moreover, the administration of probiotics by live food was able to decrease and manipulate pathogen activity in some aquatic species (Suzer et al., 2008).

In this study, seabass larvae were used as the final host. There only a few reports emphasizing the use of $E$. hirae as probiotics in aquaculture and the present study proved that $E$.

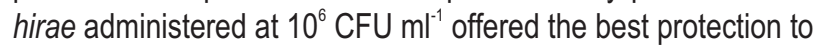
larvae after treating with $V$. harveyi. The concentration of probiont used can influence the growth performance as well as the number of pathogen load in the host. Based on the results, $10^{6} \mathrm{CFU} \mathrm{ml^{-1 }}$ appeared to be the optimal concentration that offered protection to both Artemia and seabass larvae against pathogenic V. harveyi without showing any toxicity effects to the host.
Artemia and seabass larvae incubated with probiont $E$. hirae LAB3 had lower pathogen loads after V. harveyi treatment. The results obtained showed significant decrease in the member of Vibrios in the experimental groups as compared to the control. The reduction could be an antagonism mechanism offered by the probiont for colonization activity and competition between probiotic and pathogen (Verschuere et al., 2000). Salinas et al. $(2005,2006)$ stated that administration of probiotic in culture water dramatically decreased the pathogenic bacteria activity in some teleost such as Sparus aurata.

Research done by Tachibana et al. (2020) also report on the use of probiotic Enterococcus faecium on Nile Tilapia which was able to give protection against Aeromonas hydrophila infection. Similar findings were observed in mud crab (Scylla paramamosain) treated with Enterococcus faecalis which exhibited higher survival after challenged with Vibrio parahaemolyticus (Yang et al., 2019)

Our findings revealed that the probiont concentration should be higher than or equal to that of the pathogen for the probiont to be effective. It is postulated that the mechanism of competitive exclusion occurred between the potential isolates and Vibrio spp.. They might be competing for the nutrients, spaces, and release water-soluble substances in order to inhibit the growth of other bacterias (Balcazar et al., 2006). Beneficial bacteria are widely used as an alternative method to control pathogens in aquaculture. However, more information is needed to understand the mechanism of action, which leads to good selection of probiotics.

In conclusion, $E$. hirae strain LAB3 demonstrated the ability to act as a probiotic which can inhibit the growth of 
pathogenic $V$. harveyi in in-vitro assay. The potential probionts successfully reduced the pathogens counts and enhanced the survival of Artemia and seabass larvae in in-vivo assay. This study revealed positive correlation between in-vitro and in-vivo assay. Therefore, this strain is a potential probiotic which can be applied in seabass cultures. In order to confirm its potential, further studies should be carried out to strengthen the results of this research.

\section{Acknowledgments}

This research was funded by Ministry of Higher Education Malaysia (MOHE) through Higher Institution Centre of Excellence (HiCoE) grant of Innovative Vaccine and Therapeutics against Fish Diseases, Vote No: 6369100, SATREPS JICA-JST COSMOS 2016-2021, Fundamental Research Grant Scheme (MOHE) Malaysia (Vote No: 5524396) and Universiti Putra Malaysia under High Performance Individual Research Grants UPM/700-2/1/GPB/2017/9553100. The first author, Fathiah Masduki was funded by MyBrain scholarship programme.

\section{References}

Aly, S.M., A.M. Abd-El-Rahman, G. John and M.F. Mohamed: Characterization of some bacteria isolated from Oreochromis niloticus and their potential use as probiotics. Aquaculture, 277, 16 (2008).

Azrin, N.A.R, E. Yuzine, M.Y. Ina-Salwany, R. Suzana, F. Masduki and M. Karim: Characterization of potential probionts from blue swimming crab Portunus pelagicus and Its antagonistic activity against Vibrio harveyi. Int. J. Biosci., 4, 292-303 (2017).

Balcázar, J.L., I. De Blas, I. Ruiz-Zarzuela, D. Cunningham, D. Vendrell and J.L. Muzquiz: The role of probiotics in aquaculture. Vet. Microbiol., 114, 173-186 (2006).

Bhaheerathan, J. I., B.P. Saravana, D. Chinnasamy, M. Thangaraj, K. Ramasamy, M. Thirunavukkarasu and P. Paramasivam: Growth and survival promotion of a probiotic bacterium Enterococcus durans enriched Artemia nauplii on the prawn Macrobrachium rosenbergii. GSC Biol. Pharm. Sci., 12, 087-101 (2020).

Defoirdt, T.: Virulence mechanisms of bacterial aquaculture pathogens and antivirulence therapy for aquaculture. Rev. Aquac., 6, 100-114 (2014).

Defoirdt, T., P. Sorgeloos and P. Bossier: Alternatives to antibiotics for the control of bacterial disease in aquaculture. Curr. Opin. Microbiol., 14, 251-258 (2011).

FAO/WHO: Evaluation of health and nutritional properties of powder milk and live lactic acid bacteria. Food and Agriculture Organization of the United Nations and World Health Organization Expert Consultation Report. FAO, Rome, Italy (2001).

Fathiah, M.: Assessment of Enterococcus hirae strain LAB3 isolated from Asian seabass, Lates calcarifer (Bloch, 1970) as probiotic against Vibrio harveyi infection. Universiti Putra Malaysia (2018).

Fuller, R.: Probiotics in man and animals. J. App. Bacteriol., 66, 365-378 (1989).

Gomez-Gil, B., A. Roque and G. Velasco: Culture of the bacterial strain $\mathrm{C} 7 \mathrm{~b}$, a potential probiotic bacterium, with the microalgae Chaetoceros muelleri. Aquaculture, 211, 43-48 (2002).
Haq, M.B., H.A. Ali, A.R. Nazar and S. Shalini: Assessment of Artemia franciscana as a probable vector for WSSV transmission to Macrobrachium idella idella (Hilgendorf 1898). Inter. J. Chem. Anal. Sci., 2, 1159-1170 (2011).

Kesarcodi-Watson, A., H. Kaspar, M.J. Lategan and L. Gibson: Probiotics in aquaculture: the need, principles and mechanisms of action and screening processes. Aquaculture, 274, 1-14 (2008).

Lamari, F., K. Sadok, A. Bakhrouf and F.J. Gatesoupe: Selection of lactic acid bacteria as candidate probiotics and in vivo test on Artemia Nauplii. Aquac. Int., 22, 699-709 (2014).

Lara-Flores, M. and G. Aguirre-Guzman: The use of probiotic in fish and shrimp aquaculture. A review. In: Probiotics: Production, evaluation and uses in animal feed (Eds.: N.P. Guerra and L.P. Castro). Research Signpost 37/661 (2), Fort P.O., Trivandrum-695 023, Kerala, India (2009).

Mohapatra, S., T. Chakraborty, A.K. Prusty, P. Das, K. Paniprasad and K.N. Mohanta: Use of different microbial probiotics in the diet of rohu, Labeo rohita fingerlings: Effects on growth, nutrient digestibility and retention, digestive enzyme activities and intestinal microflora. Aquac. Nutr., 18, 1-11 (2012).

Nandi, A., G. Banerjee, S.K. Dan, K. Ghosh and A.K. Ray: Probiotic efficiency of Bacillus sp. in Labeo rohita challenged by Aeromonas hydrophila: Assessment of stress profile, haematolbiochemical parameters and immune responses. Aquac. Res., 48, 4334-4345 (2017).

Noriega, L., M. Gueimonde, B. Sánchez, A. Margolles and C.G. de los Reyes-Gavilán: Effect of the adaptation to high bile salts concentrations on glycosidic activity, survival at low $\mathrm{pH}$ and crossresistance to bile salts in Bifido bacterium. Int. J. Food Microbiol., 94,79-86 (2004).

Ransangan, J., T.M. Lal and A.H. Al-Harbi: Characterization and experimental infection of Vibrio harveyi isolated from diseased Asian seabass (Lates calcarifer). Malays. J. Microbiol., 8, 104-115 (2012).

Romero, J., C.G. Feijoó and P. Navarrete: Antibiotics in aquaculture-use, abuse and alternatives. In: Health and Environment in Aquaculture. InTech (2012). DOI:10.5772/28157

Salinas, I., A. Cuesta, M.A. Esteban and J. Meseguer: Dietary administration of Lactobacillus delbrüeckii and Bacillus subtilis, single or combined, on gilthead seabream cellular innate immune responses. Fish Shellfish Immun., 19, 67-77 (2005).

Salinas, I., P. Díaz-Rosales, A. Cuesta, J. Meseguer, M. Chabrillón, M.A. Morinigo and M.A. Esteban: Effect of heat-inactivated fish and non-fish derived probiotics on the innate immune parameters of a teleost fish (Sparus aurata L.). Vet. Immunol. Immunopathol., 111, 279-286 (2006).

Seenivasan, C., P.S. Bhavan, S. Radhakrishnan and R. Shanthi: Enrichment of Artemia nauplii with Lactobacillus sporogenes for enhancing the survival, growth and levels of biochemical constituents in the post-larvae of the freshwater prawn Macrobrachium rosenbergii. Turk. J. Fish. Aquat. Sci., 12 (2012).

Sayes, C., Y. Leyton and C. Riquelme: Probiotic bacteria as an healthy alternative for fish aquaculture. Antibiotics use in animals, Savic, S, editor. Rijeka, Croatia: InTech Publishers, 115-132 (2018).

Stentiford, G.D., D.M. Neil, E.J. Peeler, J.D. Shields, H.J. Small, T.W. Flegel and J. Lotz: Disease will limit future food supply from the global crustacean fishery and aquaculture sectors. J. Invertebr. Pathol., 110, 141-157 (2012). 
Suzer, C., D. Çoban, H.O. Kamaci, S. Saka, K. Firat, O.O. Otgucuoğlu and H. Küçüksari: Lactobacillus spp. bacteria as probiotics in gilthead sea bream (Sparus aurata, L.) larvae: Effects on growth performance and digestive enzyme activities. Aquaculture, 280, 140-145 (2008).

Soltanian, S., J. Dhont, P. Sorgeloos and P. Bossier: Influence of different yeast cell-wall mutants on performance and protection against pathogenic bacteria (Vibrio campbellii) in gnotobiotically-grown Artemia. Fish Shellfish Immunol., 23, 141-153 (2007).

Swain, S.M., C. Singh and V. Arul: Inhibitory activity of probiotics Streptococcus phocae PI80 and Enterococcus faecium MC13 against vibriosis in shrimp Penaeus monodon. World J. Microbiol. Biotech., 25, 697-703 (2009).

Tachibana, L., G.S. Telli, D. de Carla Dias, G.S. Gonçalves, C.M. Ishikawa, R.B. Cavalcante and M.J.T. Ranzani-Paiva: Effect of feeding strategy of probiotic Enterococcus faecium on growth performance, hematologic, biochemical parameters and nonspecific immune response of Nile tilapia. Aquaculture Reports, 16, 100277 (2020)
Vanmaele, S., T. Defoirdt, I. Cleenwerck, P. De Vos and P. Bossier: Characterization of the virulence of Harveyi clade vibrios isolated from a shrimp hatchery in vitro and in vivo, in a brine shrimp (Artemia franciscana) model system. Aquaculture, 435, 28-32 (2015)

Verschuere, L., G. Rombaut, P. Sorgeloos and W. Verstraete: Probiotic bacteria as biological control agents in aquaculture. Microbiol. Mol. Biol. Rev., 64, 655-671 (2000).

Villamil, L., A. Figueras, M. Planas and B. Novoa: Control of Vibrio alginolyticus in Artemia culture by treatment with bacterial probiotics. Aquaculture, 219, 43-56 (2003).

Wang, Q., L. Cheng, J. Liu, Z. Li, S. Xie and S.S. De Silva: Freshwater aquaculture in PR China: trends and prospects. Rev. Aquacult., 7, 283-302 (2015).

Yang, Q., Y. Lü, M. Zhang, Y. Gong, Z. Li, N.T. Tran and S. Li: Lactic acid bacteria, Enterococcus faecalis $\mathrm{Y} 17$ and Pediococcus pentosaceus $\mathrm{G} 11$, improved growth performance, and immunity of mud crab (Scylla paramamosain). Fish Shellfish Immun., 93, 135143 (2019) 